\title{
Role of Endothelial Cells in Acute and Chronic Thrombosis
}

\author{
Magdalena L. Bochenek ${ }^{1,2,3,4}$ Katrin Schäfer $2,3,4$ \\ ${ }^{1}$ Center for Thrombosis and Hemostasis, University Medical Center \\ Mainz, Mainz, Germany \\ ${ }^{2}$ Center for Cardiology, Cardiology I, University Medical Center \\ Mainz, Mainz, Germany \\ ${ }^{3}$ Deutsches Zentrum für Herz-Kreislauf-Forschung e.V., Partner Site \\ Rhein Main, Mainz, Germany \\ ${ }^{4}$ Center for Translational Vascular Biology, University Medical Center \\ Mainz, Mainz, Germany
}

Hämostaseologie 2019;39:128-139.

\author{
Address for correspondence Katrin Schäfer, MD, Center for \\ Cardiology, Cardiology I, University Medical Center of the Johannes \\ Gutenberg University, Mainz, Germany \\ (e-mail: katrin.schaefer@unimedizin-mainz.de).
}

\begin{abstract}
Keywords

- arterial

- endothelial dysfunction

- thrombosis

- thrombus resolution

- venous
\end{abstract}

Zusammenfassung
Haemostasis encompasses a set of strictly regulated actions, such as vasoconstriction, platelet activation and blood coagulation. Endothelial cells play a crucial role in all of these processes and are an integral part of the vascular response to injury resulting in thrombus formation. Healthy endothelium expresses mediators to prevent platelet activation, including prostacyclin and nitric oxide, and to inhibit coagulation, such as thrombomodulin or RNase1. Upon activation, endothelial cells expose von Willebrand factor, integrins and other receptors to interact with activated platelets, erythrocytes and coagulation factors, respectively, resulting in blood clot formation. The endothelial cell response to cytokines and growth factors released from activated platelets and immune cells abundantly present in arterial and venous thrombi also plays an important role for thrombus resolution, whereas failure to completely resolve thrombi may initiate fibrotic remodelling and chronic vascular occlusion both in the arterial and venous tree. Therefore, endothelial cells are increasingly recognized as potential target to prevent thrombotic events and to accelerate thrombus resolution. Here, we discuss recent publications from our group in the context of other studies on the role of the endothelium during acute and chronic thrombotic events.

Die Hämostase umfasst eine Reihe von streng regulierten Abläufen wie Vasokonstriktion, Thrombozytenaktivierung und Blutgerinnung. Endothelzellen spielen eine entscheidende Rolle in all diesen Prozessen und sind ein integraler Bestandteil der vaskulären Antwort auf Verletzungen, die zur Thrombusbildung führen. Gesundes Endothel exprimiert Mediatoren zur Verhinderung der Thrombozytenaktivierung einschließlich Prostacyclin und Stickoxid und zur Hemmung der Gerinnung, wie Thrombomodulin oder RNase1. Nach der Aktivierung exponieren Endothelzellen den von Willebrand-Faktor, Integrine und andere Rezeptoren, um mit aktivierten Thrombozyten, Erythrozyten bzw. Gerinnungsfaktoren zu interagieren, was zur Bildung von Blutgerinnseln führt. Die Endothelzellenantwort auf Cytokine und Wachstumsfaktoren, die von aktivierten Blutplättchen und Immunzellen in arteriellen und venösen received

June 21, 2018

accepted after revision

September 28, 2018 (c) 2019 Georg Thieme Verlag KG Stuttgart · New York
DOI https://doi.org/ 10.1055/s-0038-1675614. ISSN 0720-9355. 
Schlüssselwörter

- arteriell

- endotheliale Dysfunktion

- Thrombose

- Thrombusauflösung

- venös
Thromben freigesetzt werden, spielt ebenfalls eine wichtige Rolle bei der Thrombusauflösung, während eine unvollständige Auflösung von Thromben fibrotische Umbauprozesse und einen chronischen Gefäßverschluss sowohl im arteriellen als auch im venösen Bereich auslösen kann. Daher werden Endothelzellen zunehmend als potenzielles Ziel zur Vorbeugung thrombotischer Ereignisse und zur Beschleunigung der Thrombusauflösung erkannt. Hier diskutieren wir aktuelle Publikationen aus unserer Gruppe im Zusammenhang mit anderen Studien zur Rolle des Endothels bei akuten und chronischen thrombotischen Ereignissen.

\section{Introduction}

Endothelial cells cover the surface of all blood vessels. They provide an important barrier between the cellular and noncellular components of the circulating blood and the interstitium; regulate tissue perfusion and supply with oxygen and nutrients; help in the recruitment of inflammatory cells and control blood pressure in conjunction with underlying smooth muscle cells and pericytes endothelial cells. The fundamental role of endothelial dysfunction for cardiovascular disease, including hypertension, coronary artery disease, chronic heart failure and peripheral artery disease, has been established in numerous clinical and experimental studies. Despite the large body of existing knowledge, new facets and functions of the endothelium, one of the largest 'organs' of our body, continue to emerge. Moreover, changes in risk factor exposure (such as increasing age, noise or air pollution) and novel therapeutic options (such as direct thrombin or factor Xa inhibitors) have yielded additional insights into the regulation and response of endothelial cells. In this short review article, we will briefly summarize the existing knowledge on the role of endothelial cells in acute and chronic thrombosis (or thrombus formation and thrombus resolution) and also highlight recent findings obtained, among others, through interactive and interdisciplinary translational research efforts at the Center for Thrombosis and Hemostasis (CTH) at the University Medical Center in Mainz, Germany.

\section{Endothelial Control of Platelet Activation and Coagulation}

Healthy endothelial cells express several molecules that counteract platelet activation and prevent coagulation and thrombus formation to maintain unobstructed blood flow and tissue perfusion. The control of platelet adhesion and activation is achieved by the expression of negatively charged heparan sulfate proteoglycans on the endothelial cell surface ${ }^{1}$ as well as by ectonucleotidases (such as CD39) catalysing the conversion of the platelet agonist adenosine diphosphate (ADP) released from activated platelets and red blood cells into adenosine. $^{2}$ Interaction of endothelial cells with platelets or stimulation with thrombin liberates prostacyclin $\mathrm{I}_{2}\left(\mathrm{PGI}_{2}\right)$ and prostaglandin $\mathrm{E}_{2}\left(\mathrm{PGE}_{2}\right)$, two potent platelet antagonists. ${ }^{3}$ The release of nitric oxide (NO) produced by endothelial nitric oxide synthase (eNOS) represents another means by which endothelial cells contribute to the prevention of platelet activation and adhesion. ${ }^{4,5}$ The parallel relaxation of vascular smooth muscle cells and vasodilation in response to NO may reduce the degree of thrombotic vessel obstruction and limit the extent of ischaemic tissue damage. ${ }^{6}$ Ribonuclease 1 (RNase1)-released from specialized intracellular storage granules, the so-called Weibel-Palade (WP) bodies, upon stimulation of endothelial cells with thrombin, tumour necrosis factor (TNF)- $\alpha$ or vascular endothelial growth factor (VEGF), ${ }^{7-9}$ degrades extracellular procoagulant RNA, and administration of RNase1 has been shown to delay arterial thrombus formation and blood vessel occlusion in mice. ${ }^{10}$

The endothelium also plays a primary role in the prevention of thrombin generation. Endogenous heparan sulphates in the endothelial glycocalyx bind the potent thrombin inhibitor antithrombin (AT). ${ }^{11}$ Endothelial cells also express specific receptors that control coagulation by binding thrombin and converting its coagulant into anticoagulant properties. Thrombomodulin, constitutively expressed on endothelial cells, in conjunction with endothelial cell protein $C$ receptor (EPCR) accelerates the thrombin-catalysed activation of protein $C$ to generate activated protein C (APC), a circulating serine protease with potent anticoagulant activity via irreversible inactivation of factors Va and VIIIa. ${ }^{12,13}$ Loss or inactivation of endothelial thrombomodulin, for example, in response to TNF $\alpha,{ }^{14}$ predisposes to coagulation activation and thrombosis. In this regard, plasma levels of soluble thrombomodulin were found to be elevated in patients with ST segment elevation myocardial infarction (STEMI) developing cardiogenic shock. ${ }^{15}$

Endothelial cells also express tissue factor pathway inhibitor (TFPI), which binds and inhibits the factor VIIa/tissue factor (TF) complex, thus preventing initiation of the extrinsic coagulation pathway. ${ }^{16}$ Mice with endothelial-specific deletion of TFPI exhibit accelerated thrombus formation in response to ferric chloride-induced arterial injury, ${ }^{17}$ and lower plasma TFPI levels have been reported in patients with STEMI, ${ }^{18}$ ischaemic stroke ${ }^{19}$ or deep vein thrombosis. ${ }^{20}$

The aforementioned properties of endothelial cells describe functions of healthy endothelium and are typically lost or shifted to a prothrombotic phenotype under the influence of cardiovascular risk factors, inflammatory or procoagulant stimuli, a phenomenon described as 'endothelial dysfunction' (see later). 


\section{Endothelial Heterogeneity Affecting Factors Controlling Haemostasis and Thrombosis}

Genetic and phenotypic differences known to exist between endothelial cells from different vascular beds and organs ${ }^{21,22}$ include surface receptors involved in haemostasis and coagulation control. For example, both thrombomodulin and EPCR are poorly expressed on brain microvascular endothelial cells, ${ }^{23,24}$ although the implications of this observation are not clear. Tissue plasminogen activator (tPA) is strongly expressed on vein endothelium, which may contribute to the higher propensity of venous thrombi to embolize. ${ }^{6} \mathrm{CD} 36$ or platelet glycoprotein IV, one of several receptors for collagen, ${ }^{25}$ is found primarily on microvascular endothelial cells. ${ }^{26}$ A short schematic overview of factors controlling thrombosis and haemostasis differentially expressed in endothelial cells lining arteries, veins and capillaries is given in -Fig. 1. The location-specific heterogeneity of endothelial cells may also contribute to the known differences in arterial, venous and microvascular thrombus composition, besides differences in hemodynamic forces between vascular beds.
Both arterial and venous endothelial cells express receptors cleaved and activated by the serine protein thrombin, protease activated receptor (PAR), which exist as four members, PAR- 1 to PAR- $4 .{ }^{27}$ The procoagulant response of the endothelium to thrombin is largely mediated by PAR- $1 .^{28}$ PAR-2 is expressed to a lesser extent on endothelial cells and, like PAR-1, responds to thrombin and activated coagulation factors, ${ }^{29}$ and also to trypsin and tryptase. ${ }^{30}$ PAR-3 and PAR-4 are not expressed on the endothelium in significant amounts. Activation of PAR-1 on endothelial cells by thrombin is responsible for the production of $\mathrm{NO}$ and $\mathrm{PGI}_{2}$ and induces the release of von Willebrand factor ( $v W F$ ) and tPA from WP bodies. $^{31}$ Thrombin-induced activation of PAR-1 and PAR-2 mediates the expression of TF in cultivated endothelial cells. $^{32}$ Of note, activation by the EPCR/APC complex switches endothelial PAR-1 signalling toward the transduction of anticoagulant and cytoprotective effects, including antiapoptotic, anti-inflammatory and proangiogenic activities. ${ }^{33}$ Therefore, the usefulness of the so-called 'parmodulins' to safely activate APC-like cytoprotective signalling in endothelial cells is currently examined in several studies. ${ }^{34}$

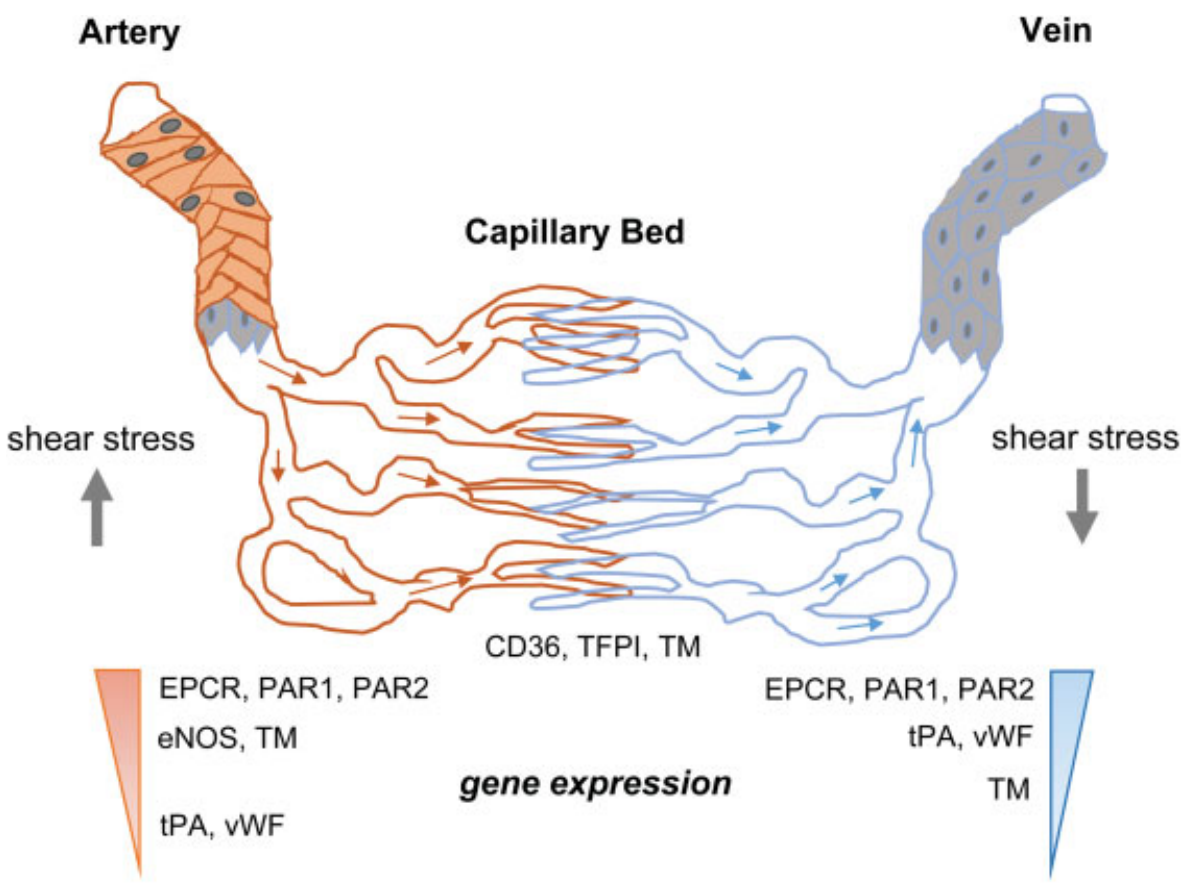

Legend

smooth muscle cell

endothelial cell

direction of blood flow

Fig. 1 Heterogeneity of endothelial cells with regard to factors involved in thrombosis and haemostasis. Schematic drawing showing endothelial expression of factors involved in preventing platelet activation and blood coagulation according to the presence of shear stress (artery vs. vein) and the endothelial bed (adapted from references 21-27). 


\section{Endothelial Integrity: An Indirect Means to Prevent Thrombosis}

The integrity of the endothelial layer per se may influence the thrombotic response. An increase in vascular permeability (such as during inflammation) may lead to a shift of fluids, albumin and molecules with a similar molecular weight, including AT and protein C, from the intravascular compartment into the extravascular space and thus reduce the amount of natural anticoagulants while at the same time increasing blood viscosity. Following thrombosis, reconstitution of endothelial integrity and coverage of prothrombotic extracellular matrix proteins present in the vessel wall and exposed after injury or atherosclerotic plaque rupture represents another important function of this cell type. Factors modulating endothelial proliferation and migration, including VEGF or transforming growth factor- $\beta$ (TGF $\beta$ ), are released from activated platelets. ${ }^{35}$ Platelet-derived VEGF is bioactive, accumulates in thrombi ${ }^{36}$ and may act as a local proangiogenic agent enhancing recanalization. ${ }^{37}$ Conversely, neutralization of VEGF or inhibition of VEGF signalling has been shown to impair venous thrombus revascularization and, consequently, resolution..$^{38,39}$ Platelet granule secretion may thus accelerate reconstitution of endothelial integrity following injury, which induces endothelial and smooth muscle cell quiescence, ${ }^{40}$ but also prevents further activation of the clotting cascade and thrombus propagation by creating a barrier between blood and the thrombus surface. ${ }^{41}$ Enhancing the regenerative capacities of the endothelium may thus constitute an indirect antithrombotic strategy. In this regard, several studies including that of our group have examined the potential of endothelial progenitor cells to enhance revascularization after arterial injury ${ }^{42,43}$ and to promote venous thrombus resolution. ${ }^{44}$ On the other hand, we could recently show that TGF $\beta$ released from activated platelets does not alter the thrombotic response to arterial injury, but impairs lesion re-endothelialization and promotes neointima formation, ${ }^{45}$ in line with its role as a negative regulator of endothelial cell proliferation. ${ }^{46}$ Moreover, TGF $\beta$ is a potent profibrotic factor and may convert endothelial cells into myofibroblasts. ${ }^{47}$ On the other hand, 'unleashing' angiogenic growth factor signalling, for example, by inhibition of protein tyrosine phosphatase-1B (PTP1B) in endothelial cells, may result in unrestricted proliferation and premature cell senescence, as recently shown by us in mice with conditional genetic deletion of PTP1B in endothelial cells and after pharmacological inhibition of PTP1B in human endothelial cells. ${ }^{48}$ Endothelial cells are present during thrombus resolution, both in the venous and the arterial system, and can be detected using CD31 immunostaining (-Fig. 2). Interestingly, CD31 (or PECAM1) was shown to actively participate in venous thrombus resolution, as shown in mice with genetic PECAM1 deficiency and humans after acute deep vein thrombosis. ${ }^{49}$

\section{Role of the Endothelium to Prevent Blood Loss after Vessel Injury}

Endothelial cells are not only equipped to ensure continuous, undisturbed blood flow by preventing platelet and leucocyte adhesion, but are also part of the first line of defence following vascular injury. For example, stimulation of endothelial cells with thrombin, histamine or bradykinin results in the acute release of endothelin- $1,{ }^{50}$ which triggers rapid vasoconstriction in smooth muscle cells to prevent blood loss after vascular injury. Within WP bodies, endothelial cells also
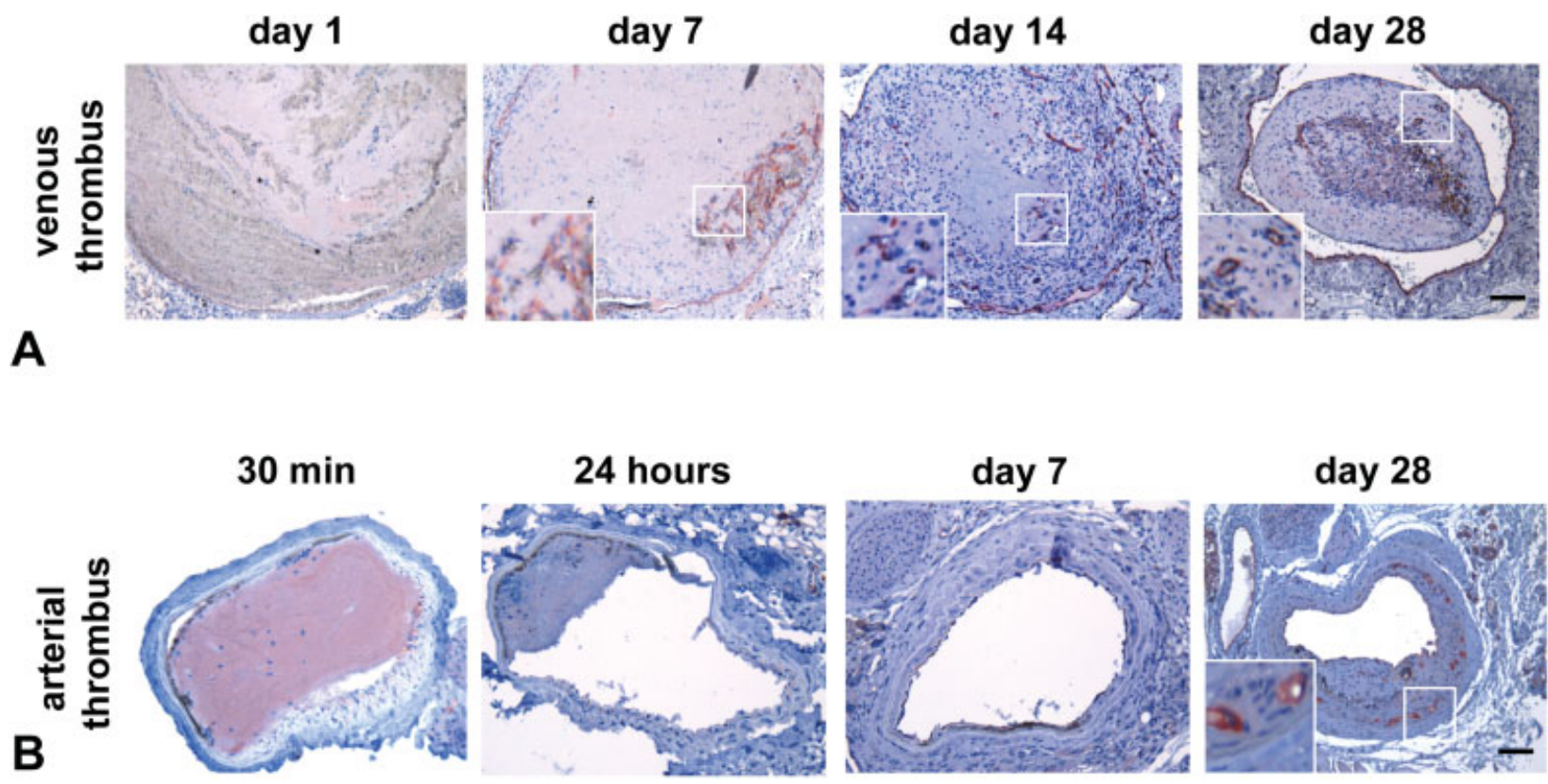

Fig. 2 Endothelial cells in venous and arterial thrombus resolution. Typical immunohistochemical images showing CD31-positive endothelial cells (red signal) at different time points following experimental induction of venous (A; IVC ligation) and arterial (B; ferric chloride injury) thrombosis. Zoom-in pictures are shown in the left corner of the picture. Scale bars represent $100 \mu \mathrm{m}$. 
store preformed haemostatic proteins, such as vWF, a large multimeric adhesion glycoprotein which stabilizes factor VIII, and binds to GPIb and GPIIbIIIa integrin receptors expressed on platelets or to extracellular matrix proteins such as collagen. ${ }^{51}$ By linking endothelial cells with activated platelets and collagen fibrils exposed after tissue damage, vWF plays a major role in haemostasis controlled by the endothelium, and experimental studies have demonstrated the importance of vWF-mediated platelet adhesion for venous thrombus formation. ${ }^{52}$ Following the lag phase of platelet-dependent adhesion and aggregation for wound healing to prevent blood loss, ADAMTS13 (which stands for disintegrin-like and metalloprotease with thrombospondin type 1 repeats-13), a vWF-specific metalloproteinase synthetized in and bound to the surface of endothelial cells, ${ }^{53}$ cleaves ultra-large vWF multimers to generate less thrombogenic fragments. ${ }^{54}$ Deficiency (genetic or acquired) in ADAMTS13 results in excessive platelet aggregation and disseminated deposition of vWF- and platelet-rich thrombi and has been discovered as pathomechanism underlying thrombotic thrombocytopenic purpura. ${ }^{55,56}$ Moreover, reduced plasma ADAMTS13 activity and increased plasma vWF are risk factors for acute myocardial infarction ${ }^{57}$ and ischaemic stroke, ${ }^{58}$ among others. ADAMTS18, another endothelial cell-derived member of this family, is cleaved and activated by thrombin to disintegrate and oxidatively fragment platelet aggregates. ${ }^{59}$ Thus, endothelial cells assist in primary clot formation after injury, but also are equipped with 'tools' to remove these aggregates and to restore tissue perfusion.

\section{Endothelial Dysfunction and Aberrant Clot Formation}

Endothelial dysfunction, defined as a shift of the properties of healthy endothelial cells toward a proadhesive, proinflammatory and prothrombotic phenotype, can be induced by a variety of conditions, including hyperlipidaemia, diabetes and smoking, and often is accompanied by an abnormally increased risk for thrombosis, but also has been implicated in impaired thrombus resolution. Activated, dysfunctional endothelial cells may contribute to the pathogenesis of thrombosis by altering the expression of pro- and antithrombotic factors. For example, stimulation of endothelial cells with proinflammatory cytokines, such as TNF $\alpha$ and interleukin-1, upregulates the production of TF and vWF, while attenuating the expression of thrombomodulin, $\mathrm{NO}$ and $\mathrm{PGI}_{2} \cdot{ }^{60}$ Of note, the majority of studies reporting TF expression in activated endothelial cells has been performed in cultured cells, whereas the endothelial expression of TF in vivo is controversial. ${ }^{61}$

Endothelial dysfunction may also be induced by hypoxia identified as a strong prothrombotic stimulus, in particular for venous thrombosis. For example, hypoxia associated with venous stasis has been shown to activate TF expression in monocytes 62 or to upregulate the antifibrinolytic factor plasminogen activator inhibitor-1 (PAI-1) in cultivated endothelial cells, ${ }^{63}$ which may contribute to impaired thrombus resolution. Hypoxia was also found to promote endothelial release of vWF and platelet binding. ${ }^{64}$ Although per se not sufficient to cause thrombosis, hypoxia was shown to promote the initiation and propagation of venous thrombosis in mice. ${ }^{65}$

Activated endothelial cells may also contribute to thrombosis via increased expression of adhesion receptors resulting in the enhanced recruitment of immune and inflammatory cells, and mice deficient in P- and/or E-selectin exhibited smaller thrombi after experimental deep vein thrombosis. ${ }^{66}$ Inflammatory cells actively participate in the thrombotic response, among others by the expression of tissue factor and the release of neutrophil extracellular traps or serine proteases (such as elastase or cathepsin $G$ ) capable of activating thrombin receptors (as recently reviewed by Iba and Levy ${ }^{67}$ ). Previous studies have demonstrated the sequential invasion of neutrophils and monocytes to developing murine venous thrombi, ${ }^{68}$ later followed by the appearance of endothelial cells and myofibroblasts. ${ }^{69}$ In our own studies, we have shown that chronological stages of thrombus resolution observed in mouse venous thrombus can also be observed in PEA (pulmonary endarterectomy) samples from patients with chronic thromboembolic pulmonary hypertension (CTEPH; - Fig. 3). Furthermore, numerous hypoxic, hypoxia-inducible factor (HIF)- $1 \alpha$ and HIF2 $\alpha$ positive cells were detected in both mouse and human thrombotic material. ${ }^{70}$ Others reported increasing levels of the HIF2 $\alpha$ during venous thrombus resolution associated with nucleated cell-dense regions and areas of neovascularization within thrombi. ${ }^{71}$ Regarding adaptive immunity, we could recently show in mice that CD4+ and CD8+ T cells rapidly infiltrate the thrombus and vein wall following experimental deep vein thrombosis and remain in the tissue throughout thrombus resolution. ${ }^{72}$ We also found, among other, that release of interferon- $\gamma$ by activated effector-memory $T$ cells determines neutrophil and monocyte recruitment as well as neovascularization and, ultimately, thrombus resolution. A role for interferon- $\gamma$ in delaying thrombus recanalization has also been suggested by others. ${ }^{73}$

\section{Novel Endothelial-Derived Mediators of Thrombosis}

Experimental evidence obtained in established mouse models of arterial and venous thrombosis ${ }^{74,75}$ has revealed additional endothelial-derived mediators with possible roles in thrombosis and prothrombotic disorders. For example, overexpression of tumour-suppressor protein 53 (p53), an ubiquitously expressed transcription factor involved in cell cycle control and apoptosis, was found to promote a prothrombotic endothelial cell phenotype in vitro via downregulation of Krüppel-like factor-2 and subsequent alterations in eNOS, thrombomodulin and PAI-1 expression. ${ }^{76}$ Our study in mice shows the importance of p53 for the risk of thrombosis in vivo, especially in states of endothelial p53 upregulation, such as in increased age. ${ }^{77}$ In this study, we could show that aging in mice was associated with p53 overexpression and apoptosis in endothelial cells lining the inferior vena cava (IVC). Moreover, aged mice developed more frequent and larger venous thrombi after being subjected to subtotal IVC ligation, whereas aged mice with endothelial-specific p53 deletion were protected from 


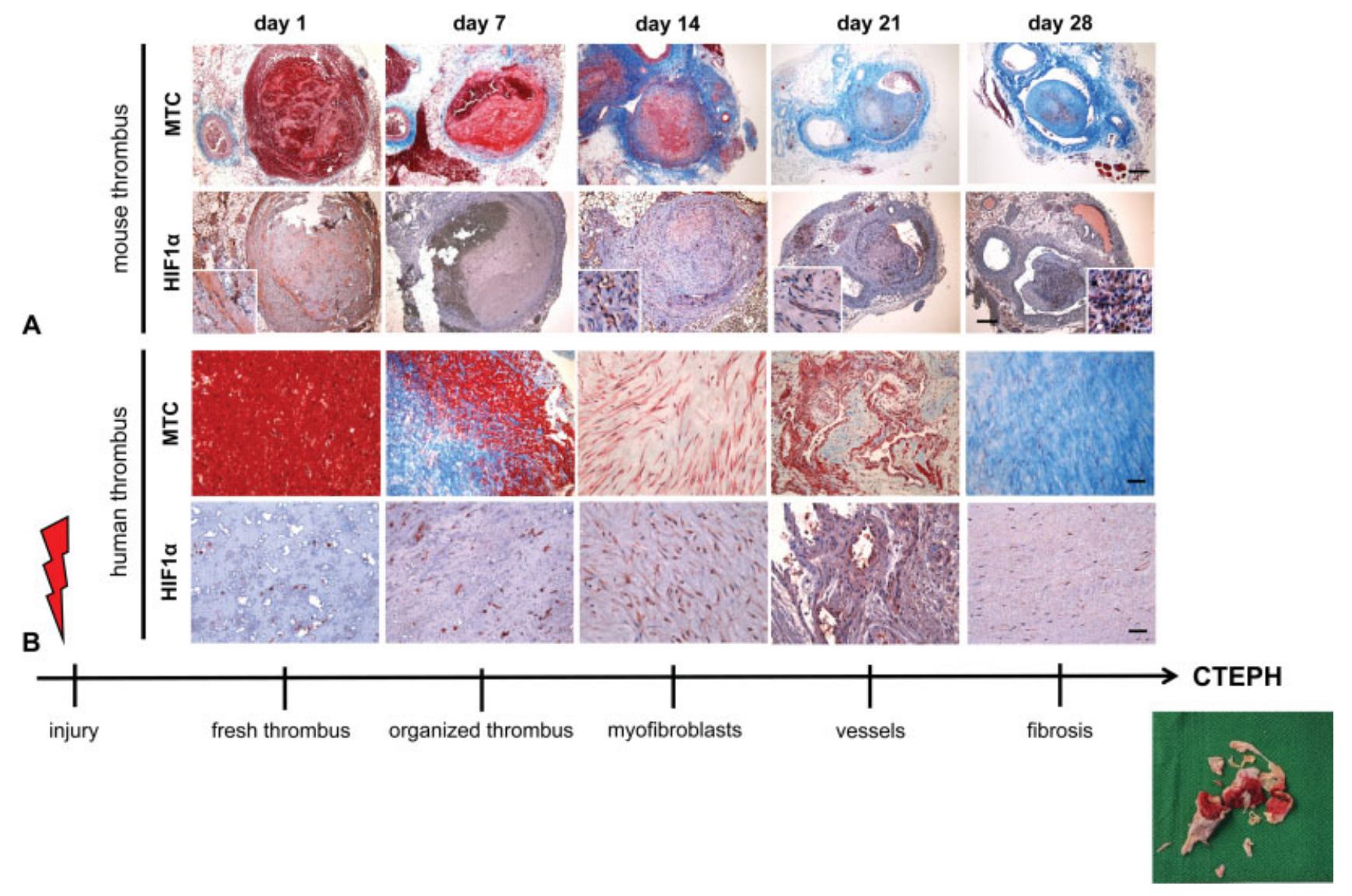

Fig. 3 Hypoxia during thrombofibrotic remodelling. Representative composite pictures of Masson Trichrome (MTC) and HIF1 $\alpha$ antibody-stained cross-sections through mouse thrombus (A) or human pulmonary endarterectomy (PEA) specimens (B) suggesting a sequence of events from thrombosis to fibrosis and the presence of hypoxia during this process. Scale bars represent $100 \mu \mathrm{m}$.

venous thrombosis. Previous studies examining the effects of age on venous thrombosis also reported a larger thrombus mass in aged mice, and elevated vein wall inflammation, and increased circulating PAI- 1 and procoagulant microparticle levels were suggested as prothrombotic stimuli. ${ }^{78}$ Others found larger venous thrombi in aged mice to be associated with increased vein wall P-selectin expression and higher soluble P-selectin. ${ }^{79}$ These and additional changes of endothelial cells with age that may underlie the prothrombotic tendency in the elderly were recently reviewed by us. ${ }^{80}$

Further analyses of primary murine endothelial cells revealed that p53 overexpression was associated with elevated expression of heparanase. The endoglycosidase heparanase is released from intracellular storage granules in response to various activation signals, including thrombin, and involved in the degradation of heparan sulphates inhibiting coagulation pathway enzymes. ${ }^{81}$ The heparanase-mediated degradation of proteoglycans in the endothelial glycocalyx may also facilitate the interaction of activated platelets with the endothelium. Others found shortened times to arterial thrombosis following vascular injury and increased in-stent thrombosis in transgenic mice overexpressing human heparanase. ${ }^{82}$ Importantly, we could show that inhibiting heparanase activity using TFPI-2 peptides restored the thrombotic phenotype of adult mice. ${ }^{77}$ TFPI2 peptides were generated by our cooperation partners Dr. Yona Nadir and Dr. Benjamin Brenner at the Rambam Health Care Campus and Technion Israel Institute of Technology in Haifa, Israel, who had previously validated their functionality to antagonize heparanase activity and venous thrombus formation. ${ }^{83,84}$ In addition to TFPI, which inhibits factor Xa and factor VIla complexed to TF, its homologue TFPI2 antagonizes a variety of serine proteases involved in blood coagulation including factor VIIa/TF, factor Xa, factor XIa, plasmin, trypsin and kallikrein. ${ }^{85}$

\section{Novel Cellular Interaction Partners with Endothelial Cells during Thrombosis and Haemostasis}

Important functions of endothelial cells are mediated in a paracrine manner: a classical example is NO produced and released by endothelial NO synthase, which activates soluble guanylate cyclase, cyclic GMP and protein kinase $\mathrm{G}$ signalling in neighbouring smooth muscle cells to control contraction and, ultimately, blood pressure. ${ }^{86}$ Via NO-induced signalling activation in platelets, endothelial cells may also control platelet activation and contribute to the antithrombotic effects of healthy endothelium. Interestingly, first reports suggest that smooth muscle cells may also play a role in thrombosis. ${ }^{87}$ Whether other paracrine factors released from 
(dysfunctional) endothelial cells may indirectly affect thrombus formation by acting on smooth muscle cells needs to be explored in further studies.

In addition to the interaction with platelets, the main cellular mediators of haemostasis, clinical and experimental evidence also suggests that endothelial cells interact with erythrocytes, a circulating cell type involved primarily in oxygen transport, but possibly also thrombosis. Although mature erythrocytes normally do not interact with healthy endothelial cells, structurally or metabolically altered erythrocytes such as from patients with sickle cell disease ${ }^{88}$ or malaria, ${ }^{89}$ and also diabetes, ${ }^{90}$ were shown to adhere to endothelial cells. Crystal structure modelling and cell-based adhesion assays revealed important interactions of the Landsteiner-Wiener blood group glycoprotein intercellular adhesion molecule-4 (ICAM-4) on erythrocyte membranes with $\alpha_{v}$-integrins highly expressed on endothelial cells. ${ }^{91}$ ICAM-4 may also bridge the interaction of erythrocytes with the fibrinogen receptor $\alpha$ IIb $\beta 3$ expressed on platelets ${ }^{92}$ or with $\alpha_{L} \beta_{2}$ and $\alpha_{M} \beta_{2}$ integrins expressed on immune cells, ${ }^{93}$ not only suggesting a mechanism how erythrocytes may contribute to vasoocclusive events in sickle cell disease ${ }^{94}$ but possibly also other prothrombotic conditions. In this regard, it was shown that calcium-loaded erythrocytes can adhere to endothelial cells via ultra-large vWF multimer strings released from thrombin-activated endothelium. ${ }^{95}$ Interestingly, splenectomy is one of the risk factors for venous thrombosis ${ }^{96}$ and its chronic sequelae, such as CTEPH ${ }^{97}$ and removal of the spleen (i.e., the organ filtering damaged and dysfunctional red blood cells from the circulation), was experimentally shown to be associated with larger and more persistent venous thrombi. ${ }^{98}$

\section{Endothelial Contribution to Thrombus Resolution}

Endothelial cells express factors, including tPA, that convert plasminogen to plasmin and thus activate fibrinolysis. Endothelial cells also express urokinase plasminogen activator which is more important during pericellular proteolysis, cell migration and wound healing including the formation of a neointima after experimental arterial thrombosis. ${ }^{99}$ Of note, metabolic and replicative stress are associated with increased expression of the antifibrinolytic factor PAI-1 in endothelial cells, ${ }^{100}$ which may contribute to the increased risk of thromboembolic events in patients with diabetes ${ }^{101}$ and older individuals. ${ }^{102}$

In addition to fibrinolysis, endothelial cells are critically involved in the restoration of vascular patency by promoting angiogenesis and the formation of new blood vessels within thrombi. Vascular obstruction and blood flow stasis result in local hypoxia and upregulation of HIF1 $\alpha$ and VEGF, as shown in mice after experimental IVC ligation and blood flow restriction. ${ }^{103}$ Inhibition of HIF1 $\alpha$ degradation by administration of the prolyl hydroxylase domain inhibitor L-mimosine increased the expression of angiogenic mediators and accelerated thrombus revascularization and resolution. ${ }^{104}$ The importance of VEGF for thrombus recanalization was documented in several studies, ${ }^{105}$ whereas other proangiogenic factors, including basic fibroblast growth factor, were found not to be effective with regard to acceleration of thrombus resolution, at least not in rats. ${ }^{106}$ Deletion of VEGFR2, the predominant endothelial cell receptor to promote VEGF effects, also delayed murine thrombus resolution. ${ }^{38}$ In addition to its role in the regulation of thrombogenesis by cleaving vWF, ADAMTS13 may modulate angiogenesis via upregulation of VEGF expression and signalling, as shown in cultivated human endothelial cells. ${ }^{107}$ Mice deficient for PECAM-1 (CD31), an adhesion glycoprotein expressed on endothelial cells and platelets, exhibited larger and more persistent venous thrombi characterized by fewer vessels and less inflammatory cells. ${ }^{49}$ Moreover, in patients with acute symptomatic deep vein thrombosis, serum levels of soluble PECAM-1, presumably truncated from the endothelial surface, were found to correlate with delayed thrombus resolution. Activated endothelial cells may also promote new vessel formation through release of TFrich microparticles and paracrine stimulation of neighbouring endothelial cells. ${ }^{108}$ This phenomenon has so far been observed in models of ischaemia-induced angiogenesis, but may also be of relevance during thrombus revascularization.

The abundantly present fibrin matrix provides an excellent scaffold for infiltrating immune and other cells during vascular tissue repair. ${ }^{109}$ Fibrin is also a potent activator of endothelial cells that triggers the secretion of WP bodies and the release of growth factors. ${ }^{110}$ In this regard, endothelial cells store, and upon stimulation with thrombin, histamine and hypoxia release angiopoietin-2 (Ang-2), the antagonist for both Ang-1 and Tie2 involved in the negative regulation of angiogenesis and promotion of vascular leakage and inflammation. ${ }^{111}$ Knockdown of Ang-2 has been shown to block thrombin-induced monocyte adhesion and ICAM-1 expression. ${ }^{112}$ Interestingly, a recent study involving network analysis of the proteomics identified elevated Ang-2 plasma levels as sensitive early marker and predictor of mortality in patients with disseminated intravascular coagulation, whereas endotoxemic mice with reduced Tie2 signalling exhibited excessive fibrin accumulation. ${ }^{113}$

The reciprocal interaction between activated endothelial cells and platelets may further stimulate angiogenesis, thrombus neovascularization and tissue repair by angiogenic growth factors secreted from platelets, including VEGF. ${ }^{114}$ Moreover, activated platelets secrete factors that enhance the interaction of endothelial cells with immune and inflammatory cells, such as RANTES or SDF1 $\alpha$, which may potentiate tissue repair. On the other hand, the interaction of factors released from activated platelets, such as TGF $\beta$, with receptors expressed on endothelial cells may also result in their phenotypic conversion to mesenchymal cells (the so-called endothelial-to-mesenchymal transition; ${ }^{47}$ ) and contribute to the fibrotic organization of thrombus material. In this regard, we observed signs of activated TGF $\beta$ signalling in PEA specimens from patients with CTEPH (Bochenek ML (PhD) et al; 2018). Although the exact molecular mechanisms that cause the excessive pulmonary artery remodelling and development of thrombofibrosis are presently unknown, CTEPH presumably develops in response to unresolved thromboembolic material within pulmonary arteries. 


\section{Antithrombotic Therapeutic Strategies Targeting the Endothelium and Vice Versa}

The aforementioned findings demonstrate that the endothelium is an essential component of the blood coagulation system and necessary to maintain normal haemostasis, whereas endothelial cell activation or injury may result in platelet activation, thrombosis and inflammation. Vice versa, factors released during platelet activation or generated during coagulation may act on endothelial cells and change their phenotype. Regarding therapeutic implications, current antithrombotic treatment regimens, including direct thrombin or factor Xa inhibitors, do not directly focus on endothelial dysfunction, but rather on the prevention of its consequences such as platelet aggregation or activation of the coagulation cascade. On the other hand, preventing the release of growth factors from activated platelets and/or the build-up of fibrin will also affect the phenotype and function of the endothelium and influence its properties during thrombus resolution and chronic wound healing processes, such as occurring in CTEPH. Pharmacological approaches to treat the prothrombotic complications of endothelial dysfunction include, but are not limited to, available or already used drugs with known endothelial-protective effects, such as angiotensin-converting enzyme inhibitors, angiotensin AT1 receptor blockers, $\beta$-blockers, calcium channel blockers, antioxidants, endothelial NO synthase enhancers, phosphodiesterase 5 inhibitors, or statins, which may directly or indirectly improve endothelial properties involved in the prevention of platelet aggregation and thrombus formation, and also fibrinolysis. ${ }^{115}$ Although still at the experimental stage, we and others could establish the efficacy of potential novel therapeutic strategies, such as TFPI2 peptides, for their potential to limit the extent of acute venous thrombosis in mice. $^{77,83,84}$

\section{Concluding Remarks and Outlook}

Endothelial cells are an essential component of the blood coagulation system and their integrity and functionality is critical to maintain haemostasis and to prevent platelet activation and thrombosis. In addition to affecting the three components of haemostasis, as outlined in Virchow's triad of arterial and venous thrombus formation, the endothelium is crucial also for the chronic vascular response to a thrombotic event by regulation of angiogenesis, inflammation and tissue repair. Future studies will have to focus more on the reciprocal interaction of endothelial cells with coagulation factors and other vascular cell types, not only in blood but also in other haematopoietic and non-haematopoietic compartments.

\section{Authors' Contribution}

M.L.B. and K.S. wrote the manuscript and acquired funding. Both authors have read and approved the final manuscript.

\section{Conflict of Interest}

The authors declare no competing financial interests.

\section{Acknowledgement}

This study was supported by the Bundesministerium für Bildung und Forschung (BMBF 01E01503 [EDU V10] to M. L.B.; BMBF 01E01003 and BMBF 01E01503 to K.S.).

\section{References}

1 Colburn P, Buonassisi V. Anti-clotting activity of endothelial cell cultures and heparan sulfate proteoglycans. Biochem Biophys Res Commun 1982;104(01):220-227

2 Marcus AJ, Broekman MJ, Drosopoulos JH, et al. The endothelial cell ecto-ADPase responsible for inhibition of platelet function is CD39. J Clin Invest 1997;99(06):1351-1360

3 Moncada S, Gryglewski R, Bunting S, Vane JR. An enzyme isolated from arteries transforms prostaglandin endoperoxides to an unstable substance that inhibits platelet aggregation. Nature 1976;263(5579):663-665

4 Mellion BT, Ignarro LJ, Ohlstein EH, Pontecorvo EG, Hyman AL, Kadowitz PJ. Evidence for the inhibitory role of guanosine 3', 5'monophosphate in ADP-induced human platelet aggregation in the presence of nitric oxide and related vasodilators. Blood 1981; 57(05):946-955

5 Radomski MW, Palmer RM, Moncada S. Endogenous nitric oxide inhibits human platelet adhesion to vascular endothelium. Lancet 1987;2(8567):1057-1058

6 Yau JW, Teoh H, Verma S. Endothelial cell control of thrombosis. BMC Cardiovasc Disord 2015;15:130

7 Landré JB, Hewett PW, Olivot JM, et al. Human endothelial cells selectively express large amounts of pancreatic-type ribonuclease (RNase 1). J Cell Biochem 2002;86(03):540-552

8 Gansler J, Preissner KT, Fischer S. Influence of proinflammatory stimuli on the expression of vascular ribonuclease 1 in endothelial cells. FASEB J 2014;28(02):752-760

9 Lollar P, Owen WG. Clearance of thrombin from circulation in rabbits by high-affinity binding sites on endothelium. Possible role in the inactivation of thrombin by antithrombin III. J Clin Invest 1980;66(06):1222-1230

10 Kannemeier C, Shibamiya A, Nakazawa F, et al. Extracellular RNA constitutes a natural procoagulant cofactor in blood coagulation. Proc Natl Acad Sci U S A 2007;104(15):6388-6393

11 Nieuwdorp M, van Haeften TW, Gouverneur MC, et al. Loss of endothelial glycocalyx during acute hyperglycemia coincides with endothelial dysfunction and coagulation activation in vivo. Diabetes 2006;55(02):480-486

12 Van de Wouwer M, Collen D, Conway EM. Thrombomodulin-protein C-EPCR system: integrated to regulate coagulation and inflammation. Arterioscler Thromb Vasc Biol 2004;24(08):1374-1383

13 Loghmani H, Conway EM. Exploring traditional and nontraditional roles for thrombomodulin. Blood 2018;132(02):148-158

14 Moore KL, Esmon CT, Esmon NL. Tumor necrosis factor leads to the internalization and degradation of thrombomodulin from the surface of bovine aortic endothelial cells in culture. Blood 1989;73(01):159-165

15 Frydland M, Ostrowski SR, Møller JE, et al. Plasma concentration of biomarkers reflecting endothelial cell- and glycocalyx damage are increased in patients with suspected ST-Elevation myocardial infarction complicated by cardiogenic shock. Shock 2018;50 (05):538-544

16 Warn-Cramer BJ, Almus FE, Rapaport SI. Studies of the factor Xadependent inhibitor of factor VIIa/tissue factor (extrinsic pathway inhibitor) from cell supernates of cultured human umbilical vein endothelial cells. Thromb Haemost 1989;61(01):101-105

17 White TA, Johnson T, Zarzhevsky N, et al. Endothelial-derived tissue factor pathway inhibitor regulates arterial thrombosis but is not required for development or hemostasis. Blood 2010;116 (10):1787-1794 
18 Figueras J, Monasterio J, Lidón RM, Sambola A, Garcia-Dorado D. Lower tissue factor inhibition in patients with ST segment elevation than in patients with non ST elevation acute myocardial infarction. Thromb Res 2012;130(03):458-462

19 Rossouw JE, Johnson KC, Pettinger M, et al. Tissue factor pathway inhibitor, activated protein $\mathrm{C}$ resistance, and risk of ischemic stroke due to postmenopausal hormone therapy. Stroke 2012;43 (04):952-957

20 Dahm A, Van Hylckama Vlieg A, Bendz B, Rosendaal F, Bertina RM, Sandset PM. Low levels of tissue factor pathway inhibitor (TFPI) increase the risk of venous thrombosis. Blood 2003;101 (11):4387-4392

21 Aird WC. Phenotypic heterogeneity of the endothelium: II. Representative vascular beds. Circ Res 2007;100(02):174-190

22 Aird WC. Phenotypic heterogeneity of the endothelium: I. Structure, function, and mechanisms. Circ Res 2007;100(02):158-173

23 Ishii H, Salem HH, Bell CE, Laposata EA, Majerus PW. Thrombomodulin, an endothelial anticoagulant protein, is absent from the human brain. Blood 1986;67(02):362-365

24 Laszik Z, Mitro A, Taylor FB Jr, Ferrell G, Esmon CT. Human protein $C$ receptor is present primarily on endothelium of large blood vessels: implications for the control of the protein $\mathrm{C}$ pathway. Circulation 1997;96(10):3633-3640

25 Tandon NN, Kralisz U, Jamieson GA. Identification of glycoprotein IV (CD36) as a primary receptor for platelet-collagen adhesion. J Biol Chem 1989;264(13):7576-7583

26 Chi JT, Chang HY, Haraldsen G, et al. Endothelial cell diversity revealed by global expression profiling. Proc Natl Acad Sci U S A 2003;100(19):10623-10628

27 Coughlin SR. Thrombin signalling and protease-activated receptors. Nature 2000;407(6801):258-264

28 O'Brien PJ, Prevost N, Molino M, et al. Thrombin responses in human endothelial cells. Contributions from receptors other than PAR1 include the transactivation of PAR2 by thrombincleaved PAR1. J Biol Chem 2000;275(18):13502-13509

29 Camerer E, Huang W, Coughlin SR. Tissue factor- and factor Xdependent activation of protease-activated receptor 2 by factor VIIa. Proc Natl Acad Sci U S A 2000;97(10):5255-5260

30 Molino M, Woolkalis MJ, Reavey-Cantwell J, et al. Endothelial cell thrombin receptors and PAR-2. Two protease-activated receptors located in a single cellular environment. J Biol Chem 1997;272 (17):11133-11141

31 Storck J, Küsters B, Zimmermann ER. The tethered ligand receptor is the responsible receptor for the thrombin induced release of von Willebrand factor from endothelial cells (HUVEC). Thromb Res 1995;77(03):249-258

32 Alm AK, Norström E, Sundelin J, Nystedt S. Stimulation of proteinase activated receptor- 2 causes endothelial cells to promote blood coagulation in vitro. Thromb Haemost 1999;81(06):984-988

33 Bouwens EA, Stavenuiter F, Mosnier LO. Mechanisms of anticoagulant and cytoprotective actions of the protein C pathway. J Thromb Haemost 2013;11(Suppl 1):242-253

34 De Ceunynck K, Peters CG, Jain A, et al. PAR1 agonists stimulate APC-like endothelial cytoprotection and confer resistance to thromboinflammatory injury. Proc Natl Acad Sci U S A 2018; 115(05):E982-E991

35 Brill A, Elinav H, Varon D. Differential role of platelet granular mediators in angiogenesis. Cardiovasc Res 2004;63(02):226-235

36 Arisato T, Hashiguchi T, Sarker KP, et al. Highly accumulated platelet vascular endothelial growth factor in coagulant thrombotic region. J Thromb Haemost 2003;1(12):2589-2593

37 Waltham M, Burnand KG, Collins M, McGuinness CL, Singh I, Smith A. Vascular endothelial growth factor enhances venous thrombus recanalisation and organisation. Thromb Haemost 2003;89(01):169-176

38 Evans CE, Grover SP, Humphries J, et al. Antiangiogenic therapy inhibits venous thrombus resolution. Arterioscler Thromb Vasc Biol 2014;34(03):565-570
39 Alias S, Redwan B, Panzenboeck A, et al. Defective angiogenesis delays thrombus resolution: a potential pathogenetic mechanism underlying chronic thromboembolic pulmonary hypertension. Arterioscler Thromb Vasc Biol 2014;34(04):810-819

40 Campbell JH, Campbell GR. Endothelial cell influences on vascular smooth muscle phenotype. Annu Rev Physiol 1986;48:295-306

41 Modarai B, Burnand KG, Humphries J, Waltham M, Smith A. The role of neovascularisation in the resolution of venous thrombus. Thromb Haemost 2005;93(05):801-809

42 Griese DP, Ehsan A, Melo LG, et al. Isolation and transplantation of autologous circulating endothelial cells into denuded vessels and prosthetic grafts: implications for cell-based vascular therapy. Circulation 2003;108(21):2710-2715

43 Schroeter MR, Leifheit M, Sudholt P, et al. Leptin enhances the recruitment of endothelial progenitor cells into neointimal lesions after vascular injury by promoting integrin-mediated adhesion. Circ Res 2008;103(05):536-544

$44 \mathrm{Li}$ WD, Li XQ. Endothelial progenitor cells accelerate the resolution of deep vein thrombosis. Vascul Pharmacol 2016;83:10-16

45 Schütz E, Bochenek ML, Riehl DR, et al. Absence of transforming growth factor beta 1 in murine platelets reduces neointima formation without affecting arterial thrombosis. Thromb Haemost 2017; 117(09):1782-1797

46 Heimark RL, Twardzik DR, Schwartz SM. Inhibition of endothelial regeneration by type-beta transforming growth factor from platelets. Science 1986;233(4768):1078-1080

47 Cooley BC, Nevado J, Mellad J, et al. TGF- $\beta$ signaling mediates endothelial-to-mesenchymal transition (EndMT) during vein graft remodeling. Sci Transl Med 2014;6(227):227ra34

48 Jäger M, Hubert A, Gogiraju R, Bochenek ML, Münzel T, Schäfer K. Inducible knockdown of endothelial protein tyrosine phosphatase-1B promotes neointima formation in obese mice by enhan-

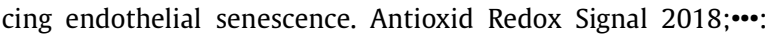
[Epub ahead of print]; . Doi: 10.1089/ars.2017.7169

49 Kellermair J, Redwan B, Alias S, et al. Platelet endothelial cell adhesion molecule 1 deficiency misguides venous thrombus resolution. Blood 2013;122(19):3376-3384

50 Kohno M, Yasunari K, Yokokawa K, et al. Thrombin stimulates the production of immunoreactive endothelin-1 in cultured human umbilical vein endothelial cells. Metabolism 1990;39(10): 1003-1005

51 Ruggeri ZM, Mendolicchio GL. Interaction of von Willebrand factor with platelets and the vessel wall. Hamostaseologie 2015; 35(03):211-224

52 Brill A, Fuchs TA, Chauhan AK, et al. von Willebrand factormediated platelet adhesion is critical for deep vein thrombosis in mouse models. Blood 2011;117(04):1400-1407

53 Turner N, Nolasco L, Tao Z, Dong JF, Moake J. Human endothelial cells synthesize and release ADAMTS-13. J Thromb Haemost 2006;4(06):1396-1404

54 Vomund AN, Majerus EM. ADAMTS13 bound to endothelial cells exhibits enhanced cleavage of von Willebrand factor. J Biol Chem 2009;284(45):30925-30932

55 Levy GG, Nichols WC, Lian EC, et al. Mutations in a member of the ADAMTS gene family cause thrombotic thrombocytopenic purpura. Nature 2001;413(6855):488-494

56 Lämmle B, Kremer Hovinga JA, George JN. Acquired thrombotic thrombocytopenic purpura: ADAMTS13 activity, anti-ADAMTS13 autoantibodies and risk of recurrent disease. Haematologica 2008; 93(02):172-177

57 Kaikita K, Soejima K, Matsukawa M, Nakagaki T, Ogawa H. Reduced von Willebrand factor-cleaving protease (ADAMTS13) activity in acute myocardial infarction. J Thromb Haemost 2006; 4(11):2490-2493

58 Bongers TN, de Maat MP, van Goor ML, et al. High von Willebrand factor levels increase the risk of first ischemic stroke: influence of ADAMTS13, inflammation, and genetic variability. Stroke 2006;37(11):2672-2677 
59 Li Z, Nardi MA, Li YS, et al. C-terminal ADAMTS-18 fragment induces oxidative platelet fragmentation, dissolves platelet aggregates, and protects against carotid artery occlusion and cerebral stroke. Blood 2009;113(24):6051-6060

60 Bevilacqua MP, Pober JS, Majeau GR, Cotran RS, Gimbrone MA Jr. Interleukin 1 (IL-1) induces biosynthesis and cell surface expression of procoagulant activity in human vascular endothelial cells. J Exp Med 1984;160(02):618-623

61 Mackman N. Role of tissue factor in hemostasis, thrombosis, and vascular development. Arterioscler Thromb Vasc Biol 2004;24 (06):1015-1022

62 Lawson CA, Yan SD, Yan SF, et al. Monocytes and tissue factor promote thrombosis in a murine model of oxygen deprivation. J Clin Invest 1997;99(07):1729-1738

63 Uchiyama T, Kurabayashi M, Ohyama Y, et al. Hypoxia induces transcription of the plasminogen activator inhibitor-1 gene through genistein-sensitive tyrosine kinase pathways in vascular endothelial cells. Arterioscler Thromb Vasc Biol 2000;20(04): $1155-1161$

64 Mojiri A, Nakhaii-Nejad M, Phan WL, et al. Hypoxia results in upregulation and de novo activation of von Willebrand factor expression in lung endothelial cells. Arterioscler Thromb Vasc Biol 2013;33(06):1329-1338

65 Brill A, Suidan GL, Wagner DD. Hypoxia, such as encountered at high altitude, promotes deep vein thrombosis in mice. J Thromb Haemost 2013;11(09):1773-1775

66 Myers D Jr, Farris D, Hawley A, et al. Selectins influence thrombosis in a mouse model of experimental deep venous thrombosis. J Surg Res 2002;108(02):212-221

67 Iba T, Levy JH. Inflammation and thrombosis: roles of neutrophils, platelets and endothelial cells and their interactions in thrombus formation during sepsis. J Thromb Haemost 2018;16 (02):231-241

68 von Brühl ML, Stark K, Steinhart A, et al. Monocytes, neutrophils, and platelets cooperate to initiate and propagate venous thrombosis in mice in vivo. J Exp Med 2012;209(04):819-835

69 Wakefield TW, Linn MJ, Henke PK, et al. Neovascularization during venous thrombosis organization: a preliminary study. J Vasc Surg 1999;30(05):885-892

70 Bochenek ML, Rosinus NS, Lankeit M, et al. From thrombosis to fibrosis in chronic thromboembolic pulmonary hypertension. Thromb Haemost 2017;117(04):769-783

71 Evans CE, Wadoodi A, Humphries J, et al. Local accumulation of hypoxia-inducible factor 2 alpha during venous thrombus resolution. Thromb Res 2014;134(03):757-760

72 Luther N, Shahneh F, Brähler M, et al. Innate effector-memory T-cell activation regulates post-thrombotic vein wall inflammation and thrombus resolution. Circ Res 2016;119(12): 1286-1295

73 Nosaka M, Ishida Y, Kimura A, et al. Absence of IFN- $\gamma$ accelerates thrombus resolution through enhanced MMP-9 and VEGF expression in mice. J Clin Invest 2011;121(07):2911-2920

74 Westrick RJ, Winn ME, Eitzman DT. Murine models of vascular thrombosis (Eitzman series). Arterioscler Thromb Vasc Biol 2007;27(10):2079-2093

75 Mackman N. Mouse models, risk factors, and treatments of venous thrombosis. Arterioscler Thromb Vasc Biol 2012;32 (03):554-555

76 Kumar A, Kim CS, Hoffman TA, et al. p53 impairs endothelial function by transcriptionally repressing Kruppel-like factor 2 . Arterioscler Thromb Vasc Biol 2011;31(01):133-141

77 Bochenek ML, Bauer T, Gogiraju R, et al. The endothelial tumor suppressor p53 is essential for venous thrombus formation in aged mice. Blood Adv 2018;2(11):1300-1314

78 McDonald AP, Meier TR, Hawley AE, et al. Aging is associated with impaired thrombus resolution in a mouse model of stasis induced thrombosis. Thromb Res 2010;125(01):72-78
79 Culmer DL, Diaz JA, Hawley AE, et al. Circulating and vein wall Pselectin promote venous thrombogenesis during aging in a rodent model. Thromb Res 2013;131(01):42-48

80 Bochenek ML, Schütz E, Schäfer K. Endothelial cell senescence and thrombosis: Ageing clots. Thromb Res 2016;147:36-45

81 Vlodavsky I, Blich M, Li JP, Sanderson RD, Ilan N. Involvement of heparanase in atherosclerosis and other vessel wall pathologies. Matrix Biol 2013;32(05):241-251

82 Baker AB, Gibson WJ, Kolachalama VB, et al. Heparanase regulates thrombosis in vascular injury and stent-induced flow disturbance. J Am Coll Cardiol 2012;59(17):1551-1560

83 Axelman E, Henig I, Crispel Y, et al. Novel peptides that inhibit heparanase activation of the coagulation system. Thromb Haemost 2014;112(03):466-477

84 Crispel Y, Axelman E, Tatour M, et al. Peptides inhibiting heparanase procoagulant activity significantly reduce tumour growth and vascularisation in a mouse model. Thromb Haemost 2016; 116(04):669-678

85 Sprecher CA, Kisiel W, Mathewes S, Foster DC. Molecular cloning, expression, and partial characterization of a second human tissue-factor-pathway inhibitor. Proc Natl Acad Sci U S A 1994; 91(08):3353-3357

86 Huang PL, Huang Z, Mashimo $\mathrm{H}$, et al. Hypertension in mice lacking the gene for endothelial nitric oxide synthase. Nature 1995;377(6546):239-242

87 Inoue O, Hokamura K, Shirai T, et al. Vascular smooth muscle cells stimulate platelets and facilitate thrombus formation through platelet CLEC-2: implications in atherothrombosis. PLoS One 2015;10(09):e0139357

88 Kaul DK, Finnegan E, Barabino GA. Sickle red cell-endothelium interactions. Microcirculation 2009;16(01):97-111

89 Smith JD, Rowe JA, Higgins MK, Lavstsen T. Malaria's deadly grip: cytoadhesion of Plasmodium falciparum-infected erythrocytes. Cell Microbiol 2013;15(12):1976-1983

90 Grossin N, Wautier MP, Wautier JL. Red blood cell adhesion in diabetes mellitus is mediated by advanced glycation end product receptor and is modulated by nitric oxide. Biorheology 2009;46 (01):63-72

91 Spring FA, Parsons SF, Ortlepp S, et al. Intercellular adhesion molecule-4 binds alpha(4)beta(1) and alpha(V)-family integrins through novel integrin-binding mechanisms. Blood 2001;98 (02):458-466

92 Hermand P, Gane P, Huet M, et al. Red cell ICAM-4 is a novel ligand for platelet-activated alpha IIbbeta 3 integrin. J Biol Chem 2003;278(07):4892-4898

93 Bailly P, Tontti E, Hermand P, Cartron JP, Gahmberg CG. The red cell LW blood group protein is an intercellular adhesion molecule which binds to CD11/CD18 leukocyte integrins. Eur J Immunol 1995;25(12):3316-3320

94 Hebbel RP, Boogaerts MA, Eaton JW, Steinberg MH. Erythrocyte adherence to endothelium in sickle-cell anemia. A possible determinant of disease severity. N Engl J Med 1980;302(18): 992-995

95 Smeets MW, Bierings R, Meems H, et al. Platelet-independent adhesion of calcium-loaded erythrocytes to von Willebrand factor. PLoS One 2017;12(03):e0173077

96 Thomsen RW, Schoonen WM, Farkas DK, Riis A, Fryzek JP, Sørensen HT. Risk of venous thromboembolism in splenectomized patients compared with the general population and appendectomized patients: a 10-year nationwide cohort study. J Thromb Haemost 2010;8(06):1413-1416

97 Bonderman D, Wilkens H, Wakounig S, et al. Risk factors for chronic thromboembolic pulmonary hypertension. Eur Respir J 2009;33(02):325-331

98 Frey MK, Alias S, Winter MP, et al. Splenectomy is modifying the vascular remodeling of thrombosis. J Am Heart Assoc 2014;3 (01):e000772 
99 Schäfer K, Konstantinides S, Riedel C, et al. Different mechanisms of increased luminal stenosis after arterial injury in mice deficient for urokinase- or tissue-type plasminogen activator. Circulation 2002; 106(14):1847-1852

100 Yamamoto K, Takeshita K, Shimokawa T, et al. Plasminogen activator inhibitor- 1 is a major stress-regulated gene: implications for stress-induced thrombosis in aged individuals. Proc Natl Acad Sci U S A 2002;99(02):890-895

101 Pomero F, Di Minno MN, Fenoglio L, Gianni M, Ageno W, Dentali F. Is diabetes a hypercoagulable state? A critical appraisal. Acta Diabetol 2015;52(06):1007-1016

102 White RH. The epidemiology of venous thromboembolism. Circulation 2003;107(23, Suppl 1):I4-I8

103 Evans CE, Humphries J, Waltham M, et al. Upregulation of hypoxia-inducible factor 1 alpha in local vein wall is associated with enhanced venous thrombus resolution. Thromb Res 2011; 128(04):346-351

104 Evans CE, Humphries J, Mattock K, et al. Hypoxia and upregulation of hypoxia-inducible factor 1alpha stimulate venous thrombus recanalization. Arterioscler Thromb Vasc Biol 2010;30(12): 2443-2451

105 Modarai B, Humphries J, Burnand KG, et al. Adenovirus-mediated VEGF gene therapy enhances venous thrombus recanalization and resolution. Arterioscler Thromb Vasc Biol 2008;28(10):1753-1759

106 Varma MR, Moaveni DM, Dewyer NA, et al. Deep vein thrombosis resolution is not accelerated with increased neovascularization. J Vasc Surg 2004;40(03):536-542

107 Lee M, Keener J, Xiao J, Long Zheng X, Rodgers GM. ADAMTS13 and its variants promote angiogenesis via upregulation of VEGF and VEGFR2. Cell Mol Life Sci 2015;72(02):349-356

108 Arderiu G, Peña E, Badimon L. Angiogenic microvascular endothelial cells release microparticles rich in tissue factor that promotes postischemic collateral vessel formation. Arterioscler Thromb Vasc Biol 2015;35(02):348-357

109 Shaikh FM, Callanan A, Kavanagh EG, Burke PE, Grace PA, McGloughlin TM. Fibrin: a natural biodegradable scaffold in vascular tissue engineering. Cells Tissues Organs 2008;188(04):333-346

110 Ribes JA, Ni F, Wagner DD, Francis CW. Mediation of fibrin-induced release of von Willebrand factor from cultured endothelial cells by the fibrin beta chain. J Clin Invest 1989;84(02):435-442

111 Scholz A, Plate KH, Reiss Y. Angiopoietin-2: a multifaceted cytokine that functions in both angiogenesis and inflammation. Ann N Y Acad Sci 2015;1347:45-51

112 Rathnakumar K, Savant S, Giri H, et al. Angiopoietin-2 mediates thrombin-induced monocyte adhesion and endothelial permeability. J Thromb Haemost 2016;14(08):1655-1667

113 Higgins SJ, De Ceunynck K, Kellum JA, et al. Tie2 protects the vasculature against thrombus formation in systemic inflammation. J Clin Invest 2018;128(04):1471-1484

114 Walsh TG, Metharom P, Berndt MC. The functional role of platelets in the regulation of angiogenesis. Platelets 2015;26 (03):199-211

115 Su JB. Vascular endothelial dysfunction and pharmacological treatment. World J Cardiol 2015;7(11):719-741

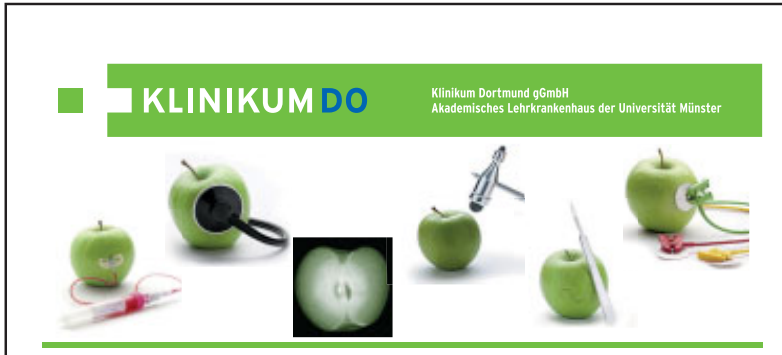

Die Klinikum Dortmund gGmbH (in Trägerschaft der Stadt) ist als Akademisches Lehrkrankenhaus der Universität Münster ein Krankenhaus der Maximalversorgung mit über 1.400 Planbetten, ca. 4.000 Mitarbeitern und verfügt (bis auf die Psychiatrie) über sämtliche medizinische Fachrichtungen. Das Klinikum behandelt jährlich über 240.000 Patientinnen und Patienten, davon rd. 65.000 stationär.

Für das Institut für Transfusionsmedizin, Laboratoriumsmedizin und Medizinische Mikrobiologie [ITLM] (Direktor: Priv.-Doz. Dr. U. Cassens) suchen wir zum nächstmöglichen Zeitpunkt und zur Vollzeitbeschäftigung einen

\section{Facharzt (w/i/m) für Laboratoriums- medizin oder Transfusionsmedizin oder einen Assistenzarzt (w/i/m) in fort- geschrittener Weiterbildung}

Wir bieten Ihnen:

- ein modernes Institut an einem großen Klinikum mit absoluter Maximalversorgung Laboratorien in der Laboratoriumsmedizin, Transfusionsmedizin und Mikrobiologie mit einem breiten Spektrum an klinisch-chemischer, immunologischer, hämatologischer, infektiologischer und molekularbiologischer Diagnostik - inklusive Konsiliartätigkeit

einen Blutspendedienst mit mehr als 20.000 Blutspenden/Jahr (Vollblutspenden/ Hämapheresen/Stammzellapheresen)

eine Blutbank, die das Klinikum Dortmund und das Umfeld mit entsprechender Diagnostik und verschiedensten Blutkomponenten versorgt

eine vielfältige und abwechslungsreiche Tätigkeit in einem sympathischen Team mit enger klinischer Anbindung

ein modernes Qualitätsmanagementsystem für alle Bereiche im Institut und Klinikum vielfältige interne und externe Fortbildungsmöglichkeiten

die komplette Weiterbildungsbefugnis in der Laboratoriumsmedizin und Transfusionsmedizin

bei geeigneter Qualifikation wird eine Besetzung und Vergütung in der Funktion eines „Oberarztes der Laboratoriumsmedizin" in Aussicht gestellt

Wir erwarten von Ihnen:

(mehrjährige) Erfahrung in der Laboratoriums- u./o. Transfusionsmedizin die dynamische Unterstützung im Labor-/Blutbank- und Blutspendebetrieb die Durchführung und Befundung der spender- und patientenseitigen Labordiagnostik die Übernahme arzneimittelrechtlicher Aufgaben und Funktionen (gemäß entsprechender Erfahrung und Qualifikation)

ein hohes Maß an Interesse und Eigeninitiative sowie Kooperationsbereitschaft und Teamfähigkeit

Die Vergütung erfolgt nach den Bestimmungen des TV-Ärzte/VKA inkl. aller im öffentlichen Dienst üblichen Sozialleistungen (einschließlich Zusatzversorgung).

Bewerbungen von Frauen sind ausdrücklich erwünscht. Bei gleicher Eignung, Befähigung und fachlicher Leistung werden Frauen nach den Bestimmungen des Landesgleichstellungsgesetzes bevorzugt berücksichtigt. Bewerbungen von schwerbehinderten Menschen sind erwünscht.

Wenn wir Ihr Interesse geweckt haben steht Ihnen für eine erste persönliche Kontaktaufnahme und weitere Auskünfte der Institutsdirektor, Herr PD Dr. Cassens, unter der Rufnummer 023195319600 gerne zur Verfügung.

Interessiert?

Dann freuen wir uns auf Ihre Onlinebewerbung unter www.klinikumdo.de 